\title{
Evaluation of some cellular immune index in HIV infected participants
}

\author{
M. IFEANYICHUKWU ${ }^{1 *}$, C.C. ONYENEKWE ${ }^{2}$, P.U. ELE ${ }^{3}$, N.K. UKIBE ${ }^{4}$, \\ S.C. MELUDU ${ }^{4}$, M.C. EZEANI ${ }^{1}$, C.C. EZECHUKWU ${ }^{1}$, G.I. AMILO ${ }^{5}$ and \\ P.U. UMEANAETO ${ }^{6}$ \\ ${ }^{1}$ Immunology Department, College of Health Sciences, Nnamdi Azikiwe University, Nnewi Campus, PMB \\ 5001 Nnewi, Anambra State, Nigeria. \\ ${ }^{2}$ Medical Laboratory Science, College of Health Sciences, Nnamdi Azikiwe University, Nnewi Campus, PMB \\ 5001 Nnewi, Anambra State, Nigeria. \\ ${ }^{3}$ Medicine Department, College of Health Sciences, Nnamdi Azikiwe University, Nnewi Campus, PMB 5001 \\ Nnewi, Anambra State, Nigeria. \\ ${ }^{4}$ Biochemistry Department, College of Health Sciences, Nnamdi Azikiwe University, Nnewi Campus, PMB \\ 5001 Nnewi, Anambra State, Nigeria. \\ ${ }^{5}$ Haematology Dept., College of Health Sciences, Nnamdi Azikiwe University, Nnewi Campus, PMB 5001 \\ Nnewi, Anambra State, Nigeria. \\ ${ }^{6}$ Parasitology Dept., Nnamdi Azikiwe University, Awka, Nigeria. \\ "Corresponding author, E-mail: moifeanyi@yahoo.co.uk
}

\begin{abstract}
The study was designed to evaluate some cellular immune index of HIV infected participants. $80 \mathrm{HIV}$ infected participants aged between 15 - 65 were recruited for the study. 45 of these participants were classified as Symptomatic HIV (Stage 11), while the remaining 35 were Asymptomatic HIV (Stage 1). Similarly, 40 HIV seronegative participants served as Control. Blood samples collected from the participants were used for HIV screening and confirmation, CD4+ T cell count, absolute lymphocyte count and percent lymphocyte transformation. The CD4+T cell count and percent Lymphocyte Transformation count were significantly lowered in HIV infected participants compared with the HIV seronegative participants ( $<0.05$ in each case). Symptomatic HIV seropositive participants also presented with lowered CD4 and percent lymphocyte transformation, compared with the asymptomatic HIV participants ( $<<0.05$ in each case). The lowered CD4+T cell count suggests possible destruction of cellular immune cells (mainly $\mathrm{Th}_{1}$ cells). While the lowered percent blast formation in HIV infection indicates functional derangement of the cellular immune cells. Meanwhile no significant difference was observed in absolute lymphocyte count among the symptomatic, asymptomatic and control participants $(\mathrm{p}>0.05)$.
\end{abstract}

(c) 2011 International Formulae Group. All rights reserved.

Keywords: Human Immunodeficiency Virus (HIV), CD4+ T Cells, Lymphocyte Transformation and Absolute lymphocyte counts.

\section{INTRODUCTION}

HIV has increased sharply in SubSaharan African and Asia, and hence calls for deep concern. HIV infection is characterized by high rate of viral replication throughout the course of the infection with resulting viral and immune mediated destruction of CD4 cells. Consequently, the infected individual 
becomes susceptible to opportunistic infections, malignancies and neurological diseases (Ukibe et al., 2010; Uchaikin, 1989). Ezeani et al. (2010) and Uchaikin (1989) also observed a dramatic lowering of the absolute numbers of $\mathrm{T}$ helper lymphocytes and an appreciable decrease of the $\mathrm{T}$ helper/T suppressor ratio, associated with high levels of circulating immune depression at the early stage of the pathological process.

Progressive HIV infection results in impairment of functional immune responses with an increase susceptibility to opportunistic infections (Schroecksnadel et al., 2009). Hong et al. (1998) reported that proliferation responses to antigens are severely impaired by HIV infection.

The present study was designed to consider some cellular index of immunity in HIV infected participants at two defined stages of HIV infection. This will allow an insight into possible pattern of these cellular immune indexes as HIV progresses especially in our locality, through the determination of CD4 count, percent lymphocyte transformation and absolute lymphocyte count.

\section{MATERIALS AND METHODS}

Methods and selection of study population Eighty (80) HIV infected participants were recruited for the study at the VCT and HIV clinic of Nnamdi Azikiwe University Teaching Hospital, Nnewi. They were aged 15- 55 years. Using WHO classification for HIV infection and CD4 count, 45 of these patients were classified Symptomatic HIV (stage 11), while the remaining 35 were classified as Asymptomatic HIV (stage 1). Forty (40) apparently healthy HIV seronegative participants drawn from students and staff population of Nnamdi Azikiwe University Teaching Hospital Nnewi, served as control.

$8 \mathrm{ml}$ of blood were collected from each participant, $3 \mathrm{ml}$ were dispensed into plain tube, and allowed to clot, and the serum extracted for HIV screening and confirmation and the remaining $5 \mathrm{ml}$ of blood, dispensed into EDTA tubes for CD4+Tcell count, by Cyflow Counter method and lymphocyte transformation counts by phytohaemagglutinin (PHA) stimulation in culture medium and absolute lymphocyte count by routine manual method.

Informed consent was obtained from those who participated in the study. The Nnamdi Azikiwe University Teaching Hospital Board of Ethical Committee approved the study design.

\section{Test for HIV infection}

The procedure was as described by the manufacturers of the kit (Acon Laboratories Inc. USA). $25 \mu 1$ of serum samples were dispensed into the "specimen pad" of the test strip. $80 \mu \mathrm{l}$ of buffer were added. The reaction was allowed for 5 minutes, the appearance of distinct red lines at test region and control region of the kit suggest positive HIV test while one distinct red line in the region of the control suggest HIV seronegative test. The appearance of the distinct red line of the control region validates the result without which the kit is assumed to be non functional.

\section{HIV confirmatory test by Western Blot as described by Popovic et al. (1984)}

$2 \mathrm{ml}$ of the reconstituted phosphate buffer PH 8.6 was added to the dish containing the nitrocellulose strip. The cells were incubated for five minutes at room temperature under slow shaking. $20 \mu \mathrm{l}$ of each patient's serum sample was added into the corresponding cell and incubated for 2 hours, at room temperature under slow shaking. The content of each dish was drained and each strip was washed twice for 5 minutes each time with $2 \mathrm{ml}$ of buffer. $2 \mathrm{ml}$ of enzyme linked anti $\mathrm{IgG}$ antibody was dispensed into each cell and incubated for 1 hour, 5 minutes at room temperature under shaking. $2 \mathrm{ml}$ of colour developing reagent (enzyme substrate) were dispensed into each cell after wasting. The colour reaction was stopped by removing reagent and washing 3 times with buffer as soon as the colour developed. The presence of shades of colour indicates positive results. No 
shades of colour representing gag antigen indicate indeterminant result.

\section{CD4+ $T$ cell count by flow cytometry}

20ul EDTA whole blood was collected into Partec test tube (Rohren tube). Then $20 \mu 1$ of CD4+T antibody were added into the tube .The contents were mixed and incubated in the dark for 15 minutes at room temperature. 800ul of CD4 buffer was gently added into the mixture and mixed gently. Then the Partec tube was plugged on the Cyflow counter and the CD4+T cells were displayed as peaks and interpreted as figures.

Lymphocyte transformation assay as described by Boyum (1964)

Lymphocyte isolation

$2 \mathrm{ml}$ each, of EDTA blood sample and balanced salt solution were dispensed into a $10 \mathrm{ml}$ test tube and the contents of the tube was carefully mixed; using a Pasteur pipette. The diluted blood sample was layered onto $3 \mathrm{ml}$ of Ficoll-paque solution in a centrifuge tube. The tube was centrifuged at $400 \mathrm{~g}$ for 30 mins at room temperature. The upper layer of the segments formed was removed, while the lymphocyte layer at the interface was pipetted into another centrifuge tube. The isolated lymphocyte was washed in $6 \mathrm{ml}$ of the balanced salt solution and finally suspended in $0.5 \mathrm{ml}$ of the balanced salt solution. Lymphocyte viability test was done by the trypan blue exclusion test.

\section{Lymphocyte transformation test}

The lymphocytes were prepared into concentrations of $1.0 \times 10^{6}$ cells $/ \mathrm{ml}$ of blood and cultured in the wells of microtitre culture plates, using TC 199 as culture medium and which had been enriched with $\mathrm{AB}$ blood group serum. $0.1 \mathrm{ml}$ of phytohaemagglutinin was added to each well of the microtitre plate. The culture mixtures were then incubated at $37^{\circ} \mathrm{C}$ for $72 \mathrm{hrs}$. At the end of the incubation period, cultures were centrifuged at 1,500 rpm for 7 minutes and the isolated Cells were then fixed in 1:10 glacial acetic acid/ alcohol mixture and re-centrifuged. The cell pellets were finally resuspended in $0.5 \mathrm{ml}$ of culture medium. Thin blood film was prepared from the isolated cells in a microscope slides. The films were allowed to dry, stained with leishmans stain. The percentage of transformed $\mathrm{T}$ cells was determined for each sample. HIV negative Control samples were similarly processed. The lymphoblasts (as the transformed cells), were counted in a light microscope using $\mathrm{x} 100$ objective and the count expressed in percentage.

\section{Statistical analysis}

The result of the analysis was statistically analyzed. Student's t, one way analysis of variance (ANOVA) was used to compare means. The analysis was performed with the use of SPSS statistical software package. $\mathrm{P}<0.05$ was considered statistically significant.

\section{RESULTS}

Lymphocyte transformation, CD4+ $T$ cell counts and absolute lymphocyte counts

The mean $( \pm \mathrm{SD})$ percent lymphocyte transformation was significantly lowered in the asymptomatic $27.5( \pm 8.7) \%$, symptomatic $14.47( \pm 5.8) \%$ HIV infected participants compared with corresponding values in control participants $59 \quad( \pm 10) \quad(\mathrm{p}<0.01)$. Similarly, the mean $( \pm \mathrm{SD})$ blood CD4+ T cell count (per ul of blood) of $300( \pm 139)$ in symptomatic HIV infected patient was significantly lower than corresponding values of $590( \pm 389)$ in asymptomatic HIV infected patients and controls $943( \pm 436)(\mathrm{p}<0.01$ in each case). The mean $( \pm \mathrm{SD}) \mathrm{CD} 4$ count in the symptomatic HIV infected patients was significantly lower than the value in asymptomatic patients $(\mathrm{p}<0.05)$. Similarly, the mean $(( \pm \mathrm{SD})$ lymphocyte transformation in symptomatic HIV infected patients was significantly lower than the asymptomatic HIV infected patients $(p<0.01)$. However the absolute lymphocyte counts show similar values in symptomatic, asymptomatic HIV infection and control participants ( $p>0.05$ ), as shown in Table 1. 
Table 1: Mean $( \pm \mathrm{SD}) \mathrm{CD} 4+\mathrm{T}$ cell count (per $\mu \mathrm{l})$, lymphocyte transformation (percent) and absolute lymphocyte count $\left(\times 10^{9}\right)$ amongst HIV infected patients and control participants.

\begin{tabular}{|c|c|c|c|}
\hline Participants & $\begin{array}{l}\text { CD4+ T cells count } \\
(\text { per } \mu \mathrm{l})\end{array}$ & $\begin{array}{l}\text { Lymphocyte } \\
\text { transformation }(\%)\end{array}$ & $\begin{array}{l}\text { Absolute lymphocyte } \\
\text { count }\left(\mathbf{x 1 0}^{9}\right)\end{array}$ \\
\hline Control $(n=40)$ & $943 \pm 436$ & $59.3 \pm 9.9$ & $1.96 \pm .38$ \\
\hline Asymptomatic $(\mathrm{n}=35)$ & $590 \pm 389$ & $27.5 \pm 8.8$ & $2.2 \pm 0.65$ \\
\hline Symptomatic $(n=45)$ & $300 \pm 139$ & $14.5 \pm 5.8$ & $2.08 \pm 0.82$ \\
\hline $\mathrm{F}(\mathrm{p})$ & $29.6(0.000)$ & $230.4(0.000)$ & $940(0.408)$ \\
\hline $\mathrm{t} 1 \mathrm{p}^{\mathrm{a}}$ & 0.014 & 0.000 & 0.167 \\
\hline $\mathrm{t} 1 \mathrm{p}^{\mathrm{b}}$ & 0.000 & 0.000 & 0.695 \\
\hline $\mathrm{t} 1 \mathrm{p}^{\mathrm{c}}$ & 0.001 & 0.000 & 0.692 \\
\hline
\end{tabular}

\section{DISCUSSION}

This study reveals lowered, CD4+ T cells count in HIV in HIV seropositives. This finding is supported by reports by Ezeani et al. (2010) and Ukibe et al. (2010). This observation may be attributed to $\mathrm{T}$ cell death caused by the HIV virus (Mark et al., 2005). This results in the numerical decline of CD4+ $\mathrm{T}$ cells; the implication is immunodeficiency state in these individuals. There are some hypotheses to account for the $\mathrm{T}$ cell - death in HIV infection; the first is programmed cell death or apoptosis, where even uninfected and therefore unstimulated cells die within first 24 hours. The second mechanism is the activation, associated lymphocyte death, by which cells stimulated by strong mitogenic stimuli such as phytohaemagglutinin (PHA) die after 48-72 hours due to hyperactive stimulation (Grossman et al., 2002). Grossman et al. (2002) also reported that antigen can induce special resting cells into activation burst, and this may be due to rapid cells proliferation and differentiation into effecter cells over period of days or week, this can contribute to the decline in the number of CD4+ T cell count.

There is also evidence that regulatory $\mathrm{T}$ lymphocyte (Tregs) are depleted during the course of HIV infection ( Weiss et al., 2002), the loss may facilitate the immune hyper activation which may in turn lead to increase
CD4+ $\mathrm{T}$ cell death associated with HIV infection.

The destruction of the CD4 $+\mathrm{T}$ cell leads to derangement of the cellular immune response. Therefore, there is derangement in the protective immunity, since the other types of immune response requires cognate help from the cellular immune response for effective immune mediation.

The role of $\mathrm{T}$ cell activation or immune activation in the pathogenesis of HIV infections has been highlighted in several reports (Hazenberg et al., 2003; Grossman et al., 2002; Sousa et al., 2002). Immune activation may be a stronger predictor of the progression of HIV disease than either the CD4+ T cell count or viral load, and may even predict treatment failure in anti-retroviral therapy (Hazenberg et al., 2003; Hunt et al., 2003; Sousa et al., 2002).

It has been suggested that chronic immune activation, arising from endemic pathogenic infections in Africa, can drive CD4+ $\mathrm{T}$ cell depletion even in HIVseronegative individuals (Borkow et al., 2001; Bentwich et al., 1996), and may convincibly contribute to HIV disease progression in coinfection ( Eggena et al., 2005) .

In this study, PHA was used to stimulate Blast Formation or lymphocyte transformation. The percent blast formation due to PHA was significantly lowered in 
participants. Only the $\mathrm{T}$ cells that have not been pre stimulated by the virus would be in a state to respond to pre-stimulation. The implication is that there is lowered blast formation ( $\mathrm{T}$ cell function) in HIV infection. This leads to induced cellular immune derangements.

Significant differences in proliferative responses between HIV infected and control participants has been reported (Shakoor, 2003; Bocchieri et al., 1995). In Africa, Eggena et al. (2005) found high levels of $\mathrm{T}$ cell activation in HIV infected Ugandans, when compared to their seronegative counterparts. We also observed that symptomatic HIV participants had lower percentage transformable $\mathrm{T}$ cells than asymptomatic group. This finding is most probably attributed to the level of disease progression. It would therefore appear from this observation that $\mathrm{T}$ cell activation or blast formation due to PHA, stimulation may correlate with disease progression. Some earlier reports had also associated a diminishing rate or percentage of lymphocyte transformation, with the progression of HIV infection towards the acquired immunodeficiency syndrome (AIDS) (Shakoor, 2003; Bansal et al., 1993). The study therefore confirms the earlier data showing that an activated immune system in HIV infected patients is associated with impaired ability to react to stimulus in vitro (Fuchs et al., 1990). The reduced proliferative response of lymphocytes to antigen and mitogen in vivo reflects HIV progress (Miedema, 1992); patients with AIDS are the most unable to respond to stimulus any more.

The finding in the study leads to conclude that the degree of $\mathrm{T}$ cell activation as determine by PHA in HIV disease and rate of CD4+T cell depletion in HIV infection appear to associate with disease progression.

\section{REFERENCES}

Bansal AS, Moran A, Otter M, Taycor R, Haeney MR, Mandal BK, 1993. Lymphocyte transformation responses to phytohaemagglutinin and pokweed mitogen in patients at different stages of HIV infection are they not measuring. $J$ Clin Pathol, 146: 8446 - 8848.

Bentwich Z, Weisman Z, Moroz C, Bar Yehuda Sand, Kalinkovich A. 1996. Immuno dys regulation in Ethiopian immigrants in Israel: relevance of helminth infection. Clin. Exp. Immunol., 103: $239-243$.

Bocchieri MH, Talle MA, Maltese LM, Ragucci IR, Hwang CC, Goldstein G. 1995. Whole blood culture for measuring mitogen induced $\mathrm{T}$ cell proliferation provides superior correlations with disease state and $\mathrm{T}$ cell phenotype in asymptomatic HIV - infected subjects. $J$. Immunol Methods, 181: 233 - 243.

Borkow G, weisman Z, Leng Q, stein M, Lalinkovich A, Wolday D, Bentwich Z. 2001. Helminths, human immunodeficiency virus and tuberculosis. Scand J. Infect Dis., 33: 568 - 571.

Boyum A. 1964. Separation of white blood cells. Nature, 204: 793-800.

Eggena MP, Barugahare B, Okello M, Mutyala S, Jones N, May Kityo C, Mugyenyi P, Cao Hugen. 2005. T cell activation in HIV-seropositive Ugandans. Differential association with viral load, CD4+ T cell depletion and co infection. The J. Infect. Dis., 199: 694 - 701.

Ezeani MC, Onyemekwu CC, Wachukwu CK, Anyiam DCD, Meluclu SC, Ukube RN, Ifeanyichukwu M, Onochie A, Anahalu I, Okafor UU. 2010. Detection of microbial antigenic components circulating immune complexes in HIV Patients: Involvement in CD4+ counts Depletion. Asian Pacific Journal of Trop. Med., 10: 828 - 832 .

Fuchs D, Shearer GM, Boswell RN. 1990. Increased serum neopterin in patients with HIV-1 infection is correlated with reduced in vitro interleukin-2 production. Clin Exp Immunol. 80: 44 - 48.

Grossman Z, Meier Schellersheim M, Sousa AE, Victorin RM, Paul WE. 2002. CD4+ $\mathrm{T}$ cell depletion in HIV infection are we 
closer to understanding the cause. Nat Med., 8: 319 - 323.

Hazenberg MD, Otto SA, Van Benthem BH. 2003. Persistant immune activation in HIV-1 infection is associated with progression to AIDS. AIDS, 17: 18811888.

Hong MA, Wakim VL, Salomao SJ.1998. IL2 and IFN-gamma, but not IL-4 secretion by peripheral blood mononuclear cells (PBMC) are related to CD4+ T cells and clinical status in Brazilian HIV-1-infected subjects. Rev Inst Med Trop Sao Paulo, 40: 351-354.

Hunt PW, Decks SG, Rodrigue B. 2003. Continued CD4 cell count increases in HIV infected adults experiencing 4 years of viral suppression on antiretroviral therapy. AIDS, 17: 1907 - 1915.

Mark P, Eggena B, Martin O, Steven M, Norma JY. Fci M, Cissy K, Peter M, Huyen C. 2005. T cell activation in HIVseropositive Ugandans; differentiation associations with viral load, CD4+ T cell depletion, and co-infection. J. Infections Disease, 191: 694 - 701.

Miedema F. 1992. Immunological abnormalities in the natural history of HIV infection: mechanisms and clinical relevance. Immunodefic Rev., 3: 173-193.

Roos MT, Miedema F, Koot M. 1995. T cell function in vitro is an independent progression marker for AIDS in human immunodeficiency virus-infected asymptomatic subjects. J Infect Dis., 171: 531536.
Popovic M, Sarngadharan MG, Read E, Gall RC. 1984. Detection, isolation and continues production of cytopathic retroviruses HTLV-111 from patients with AIDS and pre-AIDS. Science, 224: $500-5006$.

Shakoor Z. 2003. Serial evaluation of percentage of activated $\mathrm{T}$ lymphocyte in peripheral blood of human immunodeficiency virus infected individuals as a prognostic marker. Saudi Med. J., 24(6): 632 - 636.

Sousa AE, carneiro J, Meier Schellershecin M, Grossman Z, victorino RM. 2002. CD4 $\mathrm{T}$ cell depletion is linked directly to immune activation in the pathogenesis of HIV-1 and HIV-2 but only indirectly to the viral load. J Immunol., 169: 34003406.

Uchaikin. 1989. AIDS in children. Dechiatnia, 8: 71 - 79 .

Ukibe NR, Onyenekwe CC, Ahaneku JE, Meludu SE, Ukibe SN Ilika A, Ifeanyichukwu MO, Ezeani MC, Igwegwe AO, Ofiaeli $\mathrm{N}$, Onochie $\mathrm{A}$, Abor N. 2010. CD4+ T-cell count in HIV-Malaria Co-infection in adult Population in Nnewi, South Easthern Nigeria. Int. J. Biol. chem. Sci., 4(5): 1593-1601.

Weiss L, Burgard M, Cahen YD. 2002. Immunological and virological features of HIV - infected patients with increasing CD4 cell numbers despite virological failure during protease inhibitor-based therapy. HIV Med., 3: $12-20$. 